\title{
MICRONUCLEUS TEST IN FRILLFIN GOBY BATHYGOBIUS SOPORATOR (VALENCIENNES, 1873) FROM TIDE POOLS OF SALVADOR CITY, BRAZIL
}

\author{
GALINDO, T.P.S. ${ }^{1 *}$; ROSÁRIO, I.R. ${ }^{1}$; DA SILVA, E.M. ${ }^{2}$ \\ 1 - Universidade Federal da Bahia, Brasil \\ 2 - Departamento de Botânica, Instituto de Biologia, Universidade Federal da Bahia, Salvador, Brasil \\ *Corresponding author: pgalindo@ua.pt
}

\begin{abstract}
Galindo, T.P.S.; Rosário, I.R.; da Silva, E.M.; E. (2014) Micronucleus test in frillfin goby Bathygobius soporator (Valenciennes, 1873) from tide pools of Salvador city, Brazil. Braz. J. Aquat. Sci. Technol. 18(1):19-24. elSSN 19839057. DOI: 10.14210/bjast.v18n1.p19-24 The genotoxic effects of metals were evaluated in Bathygobius soporator using the micronucleus test. The frequencies of micronuclei in fish erythrocytes cells of sampling points were elevated when compared to the controls $(P<0.05)$. Micronucleus test in fish erythrocytes were useful to determine genotoxic effects of metals substances in the fish, reducing the pain and suffer of the animal testing. The first PC $(70.56 \%)$ of principal component analysis (PCA) account for almost all of the variance, and Pearson's correlation coefficient between the first PC and micronucleus frequency of sampling points $(P 1-P 10)$ was performed $(r=-0.704, P=0.023)$.
\end{abstract}

Keywords: fish, metals, genotoxicity, polycyclic aromatic hydrocarbons.

\section{INTRODUCTION}

Environmental damages due to anthropic activity is not a recent experience, though, it is disturbing because of its extreme growth in short periods of time in the last decades. Since the late 1960s and early 1970s natural scientists pointed out the apparent limits of the Earth's resources facing the growth of human population (Byrne, 1997; Knapen et al., 2004; Hubacek \& Mauerhofer, 2008). In the $20^{\text {th }}$ century, high quantities of pollutants have been generated every year for example, organic compounds like polychlorinated biphenyls (PCB), organochlorine pesticides, polycyclic aromatic hydrocarbons $(\mathrm{PAH})$ and aliphatic hydrocarbons. These substances have been released into the environment (van der Oost et al., 2003), and the aquatic ecosystems are final destinations of most of them (Ohe et al., 2004). Some studies have demonstrated toxic and genotoxic effects on living organisms, mainly metals and polycyclic aromatic hydrocarbons (Zhong et al., 1995; Song et al., 2006). PAH sources are diverse and presented in diverse matrices (Banjoo \& Nelson 2005; Bicego et al., 2006). On the other hand, metals in sediments can affect water quality, bioassimilation and bioaccumulation in aquatic organisms (Ip et al., 2007). The metals sources are mainly due to anthropogenic activities (Dalman et al., 2006).

Anthropogenic pollutants cause adverse effects in the aquatic organisms, and the biomarkers have been applied to predict the adverse effects on different organisms (van der Oost et al., 2003). For evaluation of mutagenic effects some biomarkers could be used, including the micronucleus assay, comet assay, and others (Al-Sabti \& Metcalfe, 1995). The micronucleus test is a relatively simple, reliable and sensitive to toxic effects of chemicals; it has been used to evaluate the effects of mutagenic compounds in different environments (Hayashi et al., 1998). The micronucleus are small chromatin fragments which arise as a result of chromosome breaks after clastogenic action or whole chromosomes that do not migrate during the anaphase as a result of aneugenic affects (Çavas \& Ergene-Gözükara, 2003). The goal of the present study was to evaluate the mutagenic effects in gill cells of Bathygobius soporator from polluted urban coastal environment of Salvador (Bahia).

\section{MATERIAL AND METHODS}

\section{Study area}

The study was performed in tidal pools of coastal environments of Salvador (Bahia, Brazil). A map of the sampling points is shown in Figure 1. Todos os Santos Bay is the second largest in Brazil, with an area of approximately $1000 \mathrm{~km}^{2}$. After the $1950 \mathrm{~s}$ the surroundings of Todos os Santos Bay started to be strongly developed, starting with the construction of the Mataripe Refinery Plant. The decade of 1960s was known as the most intense industrialization period within the Todos os Santos Bay. Nearly 200 industries were established in the surroundings of the Todos os Santos Bay since then, including metallurgic, textile, and chemical plants. Population growth of the metro- 
politan region of Salvador was a result of this industrial development (Porte et al., 1990; Peso-Aguiar et al., 2000; Venturini et al., 2004; Venturini \& Tomasi, 2004).

\section{Fish micronucleus test}

Frillfin goby (Bathygobius soporator) were caught in sample point $1(n=20)$ in January 2006, and were acclimatized in the laboratory in an aquarium (72L) for 90 days, with reconstituted saltwater (30PSU), at $30 \pm 3^{\circ} \mathrm{C}$. Fish were fed commercially available artificial diet (Tetra Marine) once a day. After this, the peripheral blood of gills $(n=10)$ were obtained before any treatment (negative control), and the micronucleus test was performed following the method described below, and on the fifth day after the intraperitoneal injection of cyclophosphamide (positive control) (Merck, $4 \%$ sodium chloride solution), as described in Grisolia \& Starling (2001).

On May 2007, specimens of the frillfin goby $(n=20)$, were randomly sampled in ten sampling points (P1-P10) of coastal environment of Salvador (Bahia), using $500 \mathrm{ml}$ polyethylene terephthalate (PET) bottle traps. Specimens sampling was carried out in the tidal pools of Salvador city, during low tide. After then, species were immediately transported to the laboratory. The fish seemed healthy, and the blood cells were collected immediately for ethical reasons it is absolutely necessary to minimize the pain and suffer of animal testing, and after they were returned to their habitat just after blood sampling. Erythrocytes were individually analyzed from ten of the twenty organisms randomly collected ( $n=10 ; 3000$ erythrocytes/fish) for each sampling points, using a Zeiss microscope (1000 $X$ magnification) (Metcalfe, 1988). Slides were fixed and stained according to Çavas et al. (2005). All the small inclusions of the nuclear material on erythrocytes

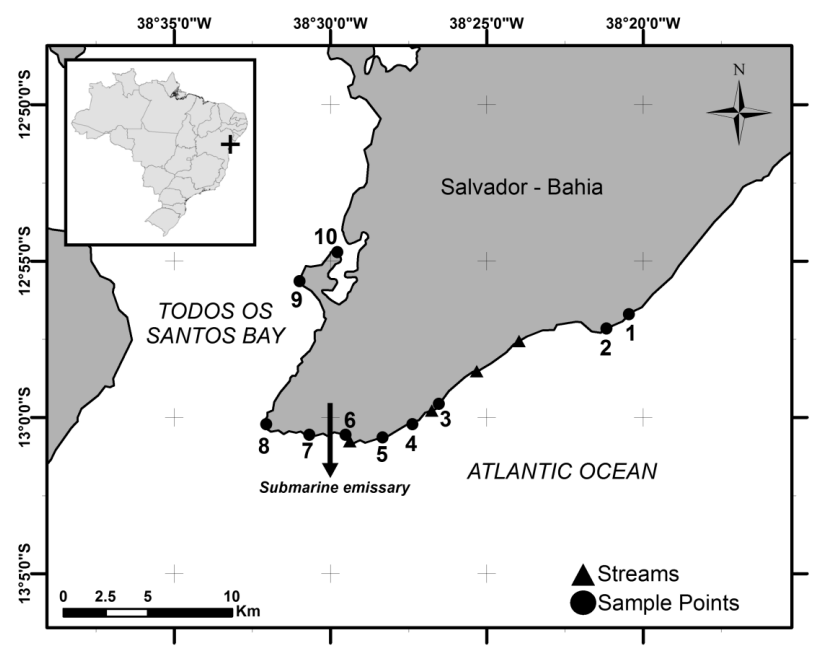

Figure 1 - Salvador city (Bahia, Brazil), sampling points and streams. cytoplasm, with size ranging from $1 / 3$ to $1 / 20$ of the main nucleus (Figure 2), were considered as micronuclei, criteria for micronuclei identification (see: Al-Sabti \& Metcalfe, 1995; Çavas et al., 2005).

Water temperature was measured in the field while the fish were collected for each site. Water samples were also collected $(n=10)$ in Falcon tubes and transported to the laboratory to immediately measure physico-chemical parameters such as dissolved oxygen, salinity and $\mathrm{pH}$. Dissolved oxygen was measured using an oximeter (LT Lutron, DO-5510), salinity was measured with a salinometer (Atago, S/Mill) and $\mathrm{pH}$ was measured with a potentiometer (Misura Line, $M L$ 1010). Surface sediment samples (5cm deep) were collected in the intertidal zone, as described by Bicego et al. (2006). Surface sediments were kept in aluminium containers for the hydrocarbons polycyclic aromatics (PAH) analysis. For metals analysis, the sediment collected was stored in plastic bags, which were transported immediately to the laboratory in a styrofoam box.

Sixteen PAH included in the Environmental Protection Agency's (EPA) priority pollutant list were analyzed using gas chromatography-mass spectrometry (CG/MS-Varian, Saturn 2200). Method 8270D (US EPA) was used for extraction of metals. Metals in sediments were analysed after the extraction with LEM-08 EPA 3051 method (US EPA), digested in a microwave oven (Provecto, DGT 100 Plus) after filtered in qualitative filter, following the D5258-92 method (ASTM, 1992) and an Atomic absorption Spectrophotometer (Varian, SpectrAA $220 \mathrm{FS}$ ) was used to determine the concentrations of $\mathrm{Cr}, \mathrm{Mn}, \mathrm{Cd}, \mathrm{Pb}, \mathrm{Hg}$ and $\mathrm{Zn}$ in the sediment. Merck standards were used to calibration curve, as well as ten white solutions to calculate the analytical detection limit (DL). Detection limits (DL) for the selected

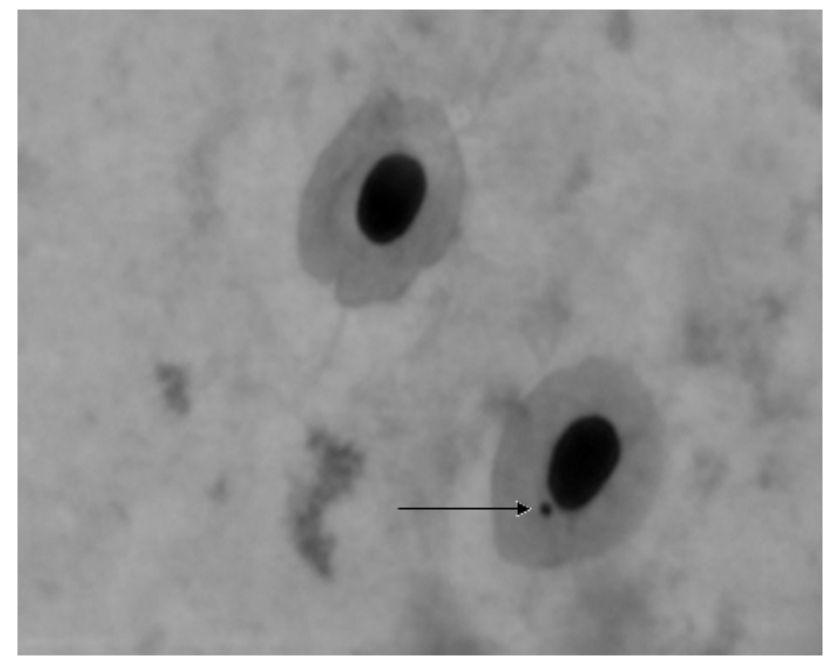

Figure 2 - The erythrocyte of $B$. soporator with the micronucleus indicated by an arrow. 
metals were: $\mathrm{Zn}\left(2.76 \mathrm{mg} \cdot \mathrm{kg}^{-1}\right), \mathrm{Mn}\left(7.28 \mathrm{mg} \cdot \mathrm{kg}^{-1}\right), \mathrm{Cr}$ (6.07mg. $\left.\mathrm{kg}^{-1}\right), \mathrm{Cd}\left(0.89 \mathrm{mg} \cdot \mathrm{kg}^{-1}\right), \mathrm{Pb}\left(10.05 \mathrm{mg} \mathrm{kg}^{-1}\right)$ and

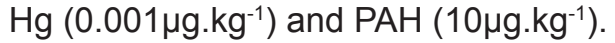

A non-parametric analysies of variance (KruskalWallis) was used to compare $\mathrm{MN}$ and controls. The normality and homogeneity were verifying using the of Kolmogorov-Smirnov and Bartlet tests, respectively. $A$ posteriori pairwise multiple comparisons (Dunn's tests, $P<0.05$ ) were employed. Then, the principal component analysis (PCA) was performed with STATISTICA 7.0. Principal component analysis (PCA) is a technique for mapping multidimensional data into lower dimensions with minimal loss of information (Kramer, 1991). The first PC accounted for almost all of the variance $(70.56 \%)$ and was used with a Pearson's correlation coefficient between the first PC and micronucleus frequency of sampling points.

\section{RESULTS}

Frequency of micronucleus is presented in Figure 3. Frequency of micronucleus was significantly higher than the negative control $\left(\mathrm{KW}_{1-10}=3.99\right.$, $P=0.00013)$ in all the sampling points, except for $\mathrm{P} 3, \mathrm{P} 5$ and $\mathrm{P} 9$, but higher than the positive control $\left(\mathrm{KW}_{1-10}=2.99, P<0.0012\right)$ only for $\mathrm{P} 1$ and $\mathrm{P} 10$.

The first PC $(70,56 \%)$ accounts for almost all of the variance (Figure 4). Therefore, Pearson's correlation coefficient between the first PC and micronucleus frequency of sample points (P1-P10) was significant (correlation test; $r=-0.704, P=0.023$ ).

Selected water quality parameters from sampling points are given in Tables 1 . Water temperature ranged from 26.7 (P5) and $32^{\circ} \mathrm{C}(\mathrm{P} 2), \mathrm{pH}$ ranged from $7.69(\mathrm{P} 10)$ and 8.39 (P5), while salinity ranged from 17.1 (P9) to 36.3 (P3 and P9). Dissolved oxygen ranged from 3.09 (P10) and 8.53mg/L (P5).
The concentrations of metals in the marine sediments are given in Table 2 . The concentrations of $\mathrm{Cd}$ and $\mathrm{Cr}$ metals were below the analytical detection limit $(\angle D L)$ in the sediments of all sample points. Manganese concentrations varied at below the analytical detection limit ( $\angle D L)$ to $95.38 \mathrm{mg}^{\mathrm{kg}} \mathrm{g}^{-1}(\mathrm{P} 6)$. Elevated $\mathrm{Pb}\left(31.28 \mathrm{mg} \cdot \mathrm{kg}^{-1}\right)$ and $\mathrm{Hg}\left(29.46 \mu \mathrm{g} \cdot \mathrm{kg}^{-1}\right)$ concentrations were observed at sample points $\mathrm{P} 10$. On the other hand, $\mathrm{Zn}$ concentrations were below the analytical detection limit at sampling points $\mathrm{P} 1$ and $\mathrm{P} 2$, and concentrations ranged from 2.8 to $7.45 \mathrm{mg}$. $\mathrm{kg}^{-1}$ (P3-P10).

$\mathrm{PAH}$ were below the analytical detection limit at all sampling points, except for the P9, that showed lower concentrations of fenantrene $\left(17.76 \mu \mathrm{g} . \mathrm{kg}^{-1}\right)$, fluoranthene $\left(60.17 \mu \mathrm{g} . \mathrm{kg}^{-1}\right)$, pyrene $\left(43.59 \mu \mathrm{g} . \mathrm{kg}^{-1}\right)$, benzo(a)anthracene $\left(29.51 \mu \mathrm{g} . \mathrm{kg}^{-1}\right)$, crysene $(27.55 \mu \mathrm{g}$. $\left.\mathrm{kg}^{-1}\right)$, benzo(b)fluoranthene $\left(14.19 \mu \mathrm{g} \cdot \mathrm{kg}^{-1}\right)$, benzo(a) pyrene $\left(12.01 \mu \mathrm{g} \cdot \mathrm{kg}^{-1}\right)$ and indenol $(1,2,3-\mathrm{cd})$ pyrene $\left(11.19 \mu \mathrm{g} \cdot \mathrm{kg}^{-1}\right)$.

\section{DISCUSSION}

In the present study significant correlations were found between the first PC of PCA analysis of sediments metals and micronucleus frequencies of sampling points from urban coastal marine areas. This correlation means that the sampling points in the Todos os Santos Bay were more polluted with metals and showed more mutagenic effects in the erythrocytes cells of the marine fish $B$. soporator.

The possibly higher concentration of metals found at the sampling points P3-P10 is because of the wide use of metals in industry and their presence in emissions from urban centres from Salvador city. Historically, the most intense industrialization period of the Todos os Santos Bay (1950s), started with the construction of the Mataripe Refinery Plant, and since

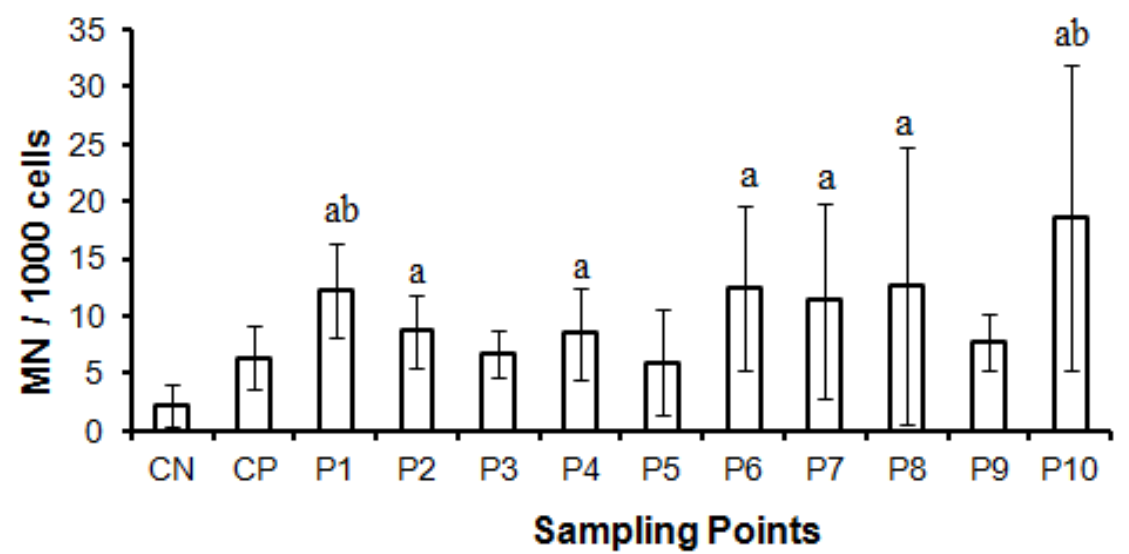

Figure 3 - The frequency of micronuclei in 1000 erythrocytes cells of $B$. soporator. CN: negative control; CP: positive control; P (1-10) sampling points $(\alpha=0.05)$; a significant difference $(P<0.05$; Anova one-way) compared to the negative control and $b$ compared with the positive control. 


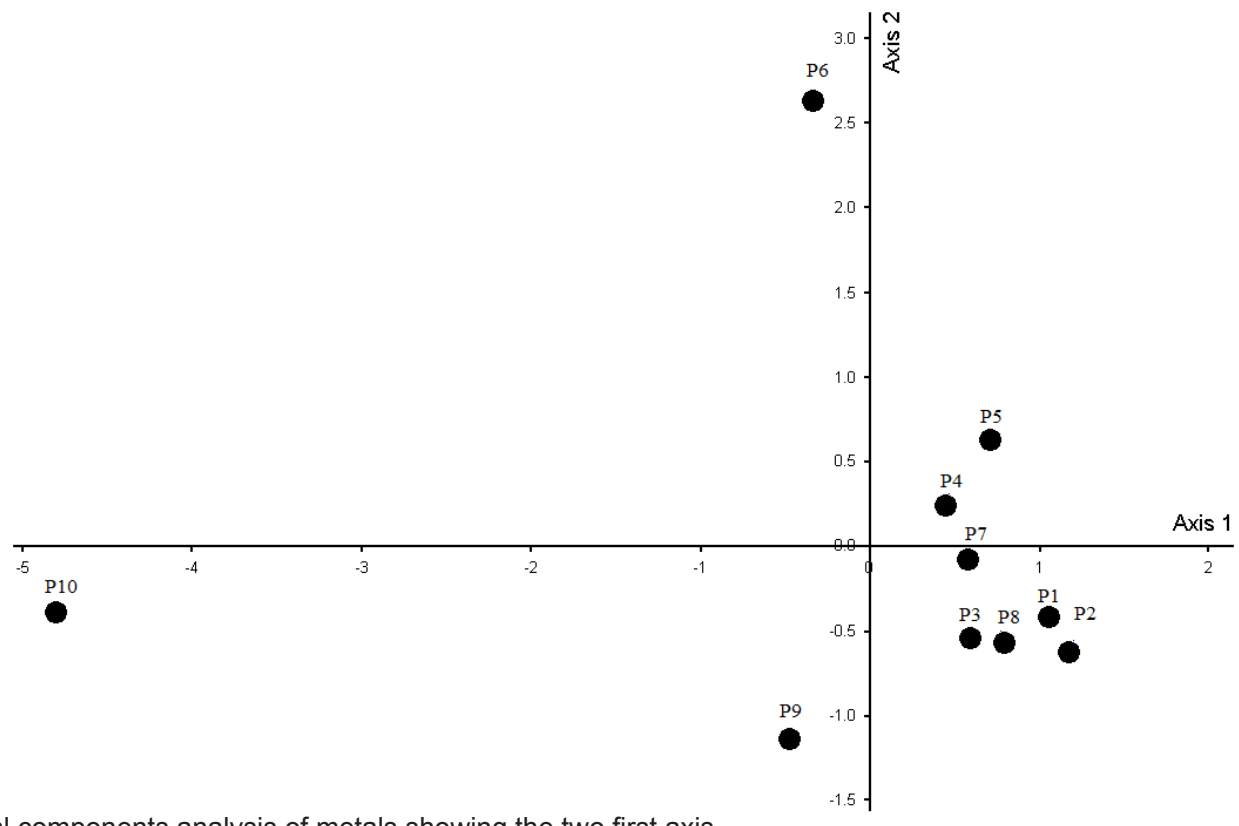

Figure 4 - Principal components analysis of metals showing the two first axis.

then nearly 200 industries were established surrounds of the bay. During the early 1970's a chlor-alkali plant was settled nearly of sampling points P9-P10 and produced discharges loaded with some 900 kg mercury year-1 (Wasserman \& Queiroz, 2004). This was an important source of pollutants discharge in the aquatic ecosystems of Salvador city.

The micronucleus frequencies at sampling points P6-P8 and P10 were higher than negative control. The sampling point $\mathrm{P} 6$ that presented higher concentration of metals like $\mathrm{Mn}, \mathrm{Hg}$ and $\mathrm{Zn}$, is located near to a small stream that load municipal wastewaters directly to the beach and near too to the submarine emissary that discharge untreated municipal wastewater from Salvador city. These discharges are the sources of metals in the sediment of the coastal environment of Salvador city. Some authors have demonstrated the genotoxic effect of the exposition to metals on fish, such as induction of micronuclei and binuclear cells from $\mathrm{Cr}$, Cu and $\mathrm{Cd}$ in Carassius gibelio and Cyprinus carpio (Çavas et al., 2005). Contamination of $\mathrm{Hg}$ related to the gold mining from the Madeira River induced micronucleus in Prochilodus nigricans, Mylossoma duriventris and Hoplias malabaricus (Porto et al., 2004). The frequencies of micronuclei in trout hepatic cells in vitro were elevated in Oncorhynchus mykiss exposed to Hg, Cd and Cu (Al-Sabti, 1995) and Cd and Cu induced micronuclei of fin cells in Carassius gibelio, Cyprinus carpio and Tilapia mossambica (Arkhipchuk \& Garango, 2005).

However, other studies showed conflicting results as follow. Both $\mathrm{Cd}$ and $\mathrm{Hg}$ induced micronuclei in eels (Anguilla anguilla) when injected, but there was no significant effect of $\mathrm{Zn}$ and $\mathrm{Cu}$. Ferraro et al. (2004) did not observe the effect in $H$. malabaricus exposed to $\mathrm{Pb}$, and Ayllon \& Garcia-Vazquez (2000) did not observe significant differences in Phoxinus phoxinus and Poecilia latipinna exposed to $\mathrm{Cd}$ and $\mathrm{Hg}$. The elevate number of micronuclei in blood cells of the marine fish in the sampling points more polluted with metals indicated chromosome breaks after clastogenic action or whole chromosomes that do not migrate during the anaphase as a result of aneugenic affects. Studies showed that metals such as $\mathrm{Pb}, \mathrm{Hg}$,

Table 1 - Mean \pm SD of temperature, salinity, dissolved oxygen, and pH of the water from tidal pools of Salvador-Ba, May 2007.

\begin{tabular}{ccccc}
\hline \hline Site & $\mathrm{T}\left({ }^{\circ} \mathrm{C}\right)$ & Salinity $(\mathrm{PSU})$ & $\mathrm{pH}$ & $\begin{array}{c}\text { Dissolved } \\
\text { oxygen }(\mathrm{mg} / \mathrm{L})\end{array}$ \\
\hline P1 & $27.90 \pm 0.74$ & $22.90 \pm 4.82$ & $8.19 \pm 0.21$ & $8.22 \pm 0.23$ \\
P2 & $32.00 \pm 1.14$ & $34.11 \pm 1.59$ & $8.39 \pm 0.18$ & $8.34 \pm 0.36$ \\
P3 & $27.00 \pm 0.00$ & $36.30 \pm 0.82$ & $8.03 \pm 0.11$ & $6.39 \pm 0.98$ \\
P4 & $31.60 \pm 0.52$ & $33.10 \pm 8.49$ & $8.30 \pm 0.08$ & $7.39 \pm 0.28$ \\
P5 & $26.70 \pm 0.67$ & $18.80 \pm 10.24$ & $8.39 \pm 0.25$ & $8.52 \pm 0.78$ \\
P6 & $29.80 \pm 0.79$ & $31.60 \pm 2.46$ & $8.13 \pm 0.07$ & $7.48 \pm 0.08$ \\
P7 & $27.00 \pm 0.47$ & $36.30 \pm 0.95$ & $7.76 \pm 0.16$ & $6.78 \pm 1.02$ \\
P8 & $27.00 \pm 0.94$ & $31.90 \pm 5.88$ & $8.06 \pm 0.11$ & $7.16 \pm 1.03$ \\
P9 & $27.50 \pm 0.71$ & $17.10 \pm 3.54$ & $8.15 \pm 0.08$ & $6.81 \pm 1.11$ \\
P10 & $28.50 \pm 0.53$ & $23.90 \pm 5.30$ & $7.69 \pm 0.13$ & $3.09 \pm 1.26$ \\
\hline \hline
\end{tabular}


Table 2 - The concentrations of heavy metals in marine sediment. Below detection limit $(<\mathrm{DL})$.

\begin{tabular}{llccccccccc}
\hline \hline Metals & $\mathrm{P} 1$ & $\mathrm{P} 2$ & $\mathrm{P} 3$ & $\mathrm{P} 4$ & $\mathrm{P} 5$ & $\mathrm{P} 6$ & $\mathrm{P} 7$ & $\mathrm{P} 8$ & $\mathrm{P} 9$ & $\mathrm{P} 10$ \\
\hline $\mathrm{Cr} \mathrm{mg} \cdot \mathrm{kg}^{-1}$ & $<\mathrm{DL}$ & $<\mathrm{DL}$ & $<\mathrm{DL}$ & $<\mathrm{DL}$ & $<\mathrm{DL}$ & $<\mathrm{DL}$ & $<\mathrm{DL}$ & $<\mathrm{DL}$ & $<\mathrm{DL}$ & $<\mathrm{DL}$ \\
$\mathrm{Mn} \mathrm{mg}_{\mathrm{kg}}{ }^{-1}$ & 16.87 & 14.91 & 16.26 & 35.81 & 45.68 & 95.38 & 27.73 & 15.77 & $<\mathrm{DL}$ & 25.98 \\
$\mathrm{Cd} \mathrm{mg} \cdot \mathrm{kg}^{-1}$ & $<\mathrm{DL}$ & $<\mathrm{DL}$ & $<\mathrm{DL}$ & $<\mathrm{DL}$ & $<\mathrm{DL}$ & $<\mathrm{DL}$ & $<\mathrm{DL}$ & $<\mathrm{DL}$ & $<\mathrm{DL}$ & $<\mathrm{DL}$ \\
$\mathrm{Pb} \mathrm{mg} \cdot \mathrm{kg}^{-1}$ & $<\mathrm{DL}$ & $<\mathrm{DL}$ & $<\mathrm{DL}$ & $<\mathrm{DL}$ & $<\mathrm{DL}$ & $<\mathrm{DL}$ & $<\mathrm{DL}$ & $<\mathrm{DL}$ & $<\mathrm{DL}$ & 31.28 \\
$\mathrm{Hg} \mathrm{kg}^{-1}$ & $<\mathrm{DL}$ & $<\mathrm{DL}$ & 1.79 & 4.08 & 2.37 & 10.76 & 2.91 & 2.52 & 15.44 & 29.46 \\
Zn mg.kg-1 & $<\mathrm{DL}$ & $<\mathrm{DL}$ & 5.01 & 4.68 & 3.11 & 7.45 & 4.40 & 2.81 & 7.63 & 23.54 \\
\hline \hline
\end{tabular}

$\mathrm{Cr}$ and $\mathrm{Cd}$ are presumed to be related to damages on DNA causing rupture of the double helix, single strand breaks, oxidative damages, mutations, chromosomal aberrations, formation of DNA adducts, effects on the DNA repair mechanism and polymerization inhibition of the actin filaments during cell's division (Ferraro et al., 2004; Çavas et al., 2005; Porto et al., 2005).

Some studies have showed hydrocarbons polycyclic aromatics (HPA) in the sediment of Todos os Santos Bay (Porte et al., 1990; Venturini \& Tomasi, 2004; Martins et al., 2005), despite of the lower concentration $(<D L)$ of HPA in the urban coastal sediment of almost sampling points showed in this work. Despite of the lower concentration of HPA in the sediment of this study, authors have also demonstrated the genotoxic effect of PAH in Anguilla anguilla (Pacheco \& Santos, 2002), and in rat splenn erythrocytes (Zhong et al., 2005). PAH and its metabolites, in the organisms, might form adducts like DNA adducts, after exposure to mutagenic chemicals (van der Oost et al., 2003), but no clear correlation of HPA and micronuclei was detected in this study.

In conclusion, this study demonstrated that there is a gradient of sediments contaminations of metals related with urban and industrial activities in the sediment of urban coastal environment of Salvador city. Sampling point $\mathrm{P} 10$ with higher concentrations of $\mathrm{Pb}$ and $\mathrm{Hg}$, situated near the deactivated chlor-alkali plant showed high frequency of micronucleus, with some metals concentrations that could cause adverse effects on aquatic organisms. The sampling points 1 and 2 , far away for high population density and recent urban occupation, showed lower concentrations of metals in the sediment. It is important to point out that the erythrocytes micronucleus tests in erythrocytes of fish solved an important bioethical task of keeping fish alive under investigation, and reduce the pain and suffering of animal testing in ecotoxicological studies.

\section{ACKNOWLEDGEMENTS}

E.M. Da Silva and T.P. Galindo acknowledge receiving scholarships from the Brazilian Research Council (CNPq) and Brazilian Coordination of Improvement of Personnel of Superior Level (CAPES), respectively. We are also indebted to Ubiratam Outeiro and Tito Galindo, who were helpful in the field and laboratory work.

\section{REFERENCES}

Al-Sabti, K. \& Metcalfe, C.D., 1995, Fish micronuclei for assessing genotoxicity in water. Genet. Toxicol., 343: 121-135.

Al-Sabti, K. \& Metcalfe, C.D., 1995, Fish micronuclei for assessing genotoxicity in water. Mutat. Res., 343: 121-135.

Arkhipchuk, V.V. \& Garanko, N.N., 2005, Using the nucleolar biomarker and the micronucleus test on in vivo fish fin cells. Ecotoxicol. Environ. Saf., 62: 42-52.

ASTM-American Society for Testing Materials. Standard pratic for acid-extraction of elements from sediments using closed vessel microwave heating. ASTM D25802 /1992.

Ayllon, F. \& Garcia-Vazquez, E., 2000, Induction of micronuclei and other nuclear abnormalities in European minnow Phoxinus phoxinus and mollie Poecilia latipinna: an assessment of he fish micronucleus test. Mutat. Res., 467: 177-186.

Banjoo, D.R. \& Nelson, P.K., 2005, Improved ultrasonic extraction procedure for the determination of polycyclic aromatic hydrocarbons in sediments. J. Chromatogr. 1066: 9-18.

Bicego, M.C., Taniguchi, S., Yogui, G.T., Montone, R.C., Silva, D.A.M., Lourenço, R.A., Martins, C.C., Sasaki, S.T., Pellizari, V.H. \& Weber, R.R., 2006, Assessment of contamination by polychlorinated biphenyls and aliphatic and aromatic hydrocarbons in sediments of the Santos and SãoVicente Estuary System, São Paulo, Brazil. Marine Poll. Bull. 52: 1784-1832.

Byrne, M.M., 1997, Is growth a dirty word? Pollution, abatement and endogenous growth. J. Devel Econ., 54: 261-284.

Çavas, T. \& Ergene-Gözükara, S., 2003, Micronuclei, nuclear lesions and interphase silver-stained nuclear organizer regions (AgNORs) as cyto-geneotoxicity indicators in Oreochromis niloticus exposed to textile mill effluent. Mutat. Res., 538: 87-91.

Çavas, T., Garanko, N.N. \& Arkhipchuk, V.V., 2005, Induction of micronuclei and binuclei in blood, gill and liver cells of fishes subchronically exposed to 
cadmium chlorid and copper sulphate. Food Chem. Toxicol., 43: 569-574.

Dalman, O., Demirak, A. \& BalciA., 2006, Determination of heavy metals $(\mathrm{Cd}, \mathrm{Pb})$ and trace elements $(\mathrm{Cu}, \mathrm{Zn})$ in sediments and fish of the Southeastern Aegean Sea (Turkey) by atomic absorption spectrometry. Food Chem., 95: 157-162.

Dalman, O., Demirak, A., \& Balc, A., 2006, Determination of heavy metals $(\mathrm{Cd}, \mathrm{Pb})$ and trace elements $(\mathrm{Cu}, \mathrm{Zn})$ in sediments and fish of the Southeastern Aegean Sea (Turkey) by atomic absorption spectrometry. Food Chem., 95: 157-162.

Ferraro, M.V.M., Fenocchio, A.S., Mantovani, M.S., Ribeiro, C.O. \& Cestari, M.M., 2004, Mutagenic effects of tributyltin and inorganic (Pbll) on the fish $\mathrm{H}$. malabaricus as evaluated using the comet assay and piscine micronucleus and chromosome aberrations test. Genet. Mol. Biol., 27: 103-107.

Grisolia, C.K. \& Starling, F.L.R.M., 2001, Micronuclei monitoring of fishes from Lake Paranoá, under influence of sewage treatment plant discharges. Mutat. Res., 491: 39-44.

Hayashi, M., Ueda, T., Uyeno, K., Wada, K., Kinae, N., Saotme, K., Tanaka, N., Takai, A., Sasaki, Y. F., Asano. N., Sofuni, T. \& Ojima, Y., 1998, Development of genotoxicity assay system that use aquatic organisms. Mutat. Res., 399: 125-133.

Hubaceka, K. \& Mauerhofer, V., 2008, Future generations: Economic, legal and institutional aspects. Futures., 40: 413-423.

Ip, C.C.M., Li, X., Zhang, G., Wai, O.W.H. \& Li, Y., 2007, Trace metal distribution in sediments of the Pearl River Estuary and the surrounding coastal area, South China. Environ. Poll., 147: 311-323.

Knapen, D., Bervoets, L., Verheyen, E. \& Blust, R., 2004, Resistance to water pollution in natural gudgeon (Gobio gobio) populations may be due to genetic adaptation. Aquat. Toxicol., 67: 155-165.

Kramer, M.A., 1991, Nonlinear principal component analysis using autoassociative neural networks. AIChE J., 37: 223-243.

Martins, L.K.P., Nascimento, I.A., Fillmann, G., King, R., Evangelista, A.J.A., Readman, J.W. \& Depledge M.H., 2005, Lysosomal responses as a diagnostic tool for the detection of chronic petroleum pollution at Todos os Santos Bay, Brazil. Environ. Res., 99: 387-396.

Metcalfe, C.D., 1988, Induction of micronuclei and nuclear abnormalities in the erythrocytes of mudminnows (Ulbra limi) and brown bullheads (Ictalurus nebulosus). Environ. Contam. Toxicol., 40: 498-495.

Ohe, T., Watanabe, T. \& Wakabayashi K., 2004, Mutagens in surface waters: a review. Mutat. Res., 567: 109-149.

Pacheco, M. \& Santos, M.A., 2002, Naphthalene and $\beta$-naphthoflavone effects on Anguilla anguilla
L. hepatic metabolism and erytrocytic nuclear abnormalities. Environ. Int., 28: 285-293.

Peso-Aguiar, M.C., Smith, D.H., Assis, R.C.F., SantaIsabel, L.M., Peixinho, S., Gouveia, E.P., Almeida, T.C.A., Andrade, W.S., Carqueija, C.R.G., Kelmo, F., Carrozo, G., Rodrigues, C.V., Carvalho, G.C. \& Jesus, A.C.S., 2000, Effects o petroleum and derivates in benthic communities at Todos os Santos Bay, Bahia, Brazil. Aquat. Eco. Health Manage., 3: 459-470.

Porte, C., Barceló, D., Tavares, T.M., Rocha, V.C \& Albaigés. J., 1990, The use of the mussel watch and molecular marker concepts in studies of hydrocarbons in a tropical bay (Todos os Santos. Bahia, Brazil). Arch. Environ. Contam. Toxicol., 19: 263-274.

Porto, J.I.R., Araújo, C.S.O. \& Feldberg E., 2004, Mutagenic effects of mercury pollution as revealed by micronucleus test on three Amazonian fish species. Environ. Res., 97: 287-292.

Song, Y.F., Wilke, B.M., Song, X.Y., Gong, P., Zhou, Q.X. \& Yang, G.F., 2006, Polycyclic aromatic hydrocarbons (PAHs), polychlorinated biphenyls (PCBs) and heavy metals (HMs) as well as their genotoxicity in soil after long-term wastewater irrigation. Chemosphere, 65: 1859-1868.

Udroiu I., 2006, The micronucleus test in piscine erythrocytes. Aquat. Toxicol., 79: 201-204.

Van Der Oost, R,, Beyer, J. \& Vermeulen, N.P.E., 2003, Fish bioaccumulation and biomarkers in environmental risk assessment: a review. Environ. Toxicol. Pharmacol., 13: 57-149.

Venturini, N. \& Tomassi, L.R., 2004, Plycyclic aromatic hydrocarbos and chages in th trophic strucure of polychate assemblages in sediments of Todos os Santos Bay Northeastern, Brazil. Mar. Poll. Bull., 48: 97-107.

Venturini, N. \& Tomassi, L.R., 2004, Polycyclic aromatic hydrocarbons and charges in the trophic structure of polychaete assemblages in sediments of Todos os Santos Bay Northeastern, Brazil. Mar. Poll. Bull., 48: 97-107.

Wasserman, J.C. \& Queiroz, E.L., 2004, The attenuation of concentrations model: a new method for assessing mercury mobility in sediments. Quím. Nova, 27(1): 17-21.

Zhong, B.Z., Gu, Z.W., Stewart, J. \& Ong, T., 1995, Micronucleus formation induced by three polycyclic aromatic hydrocarbons in rat bone marrow and spleen erythrocytes following intratracheal instillation. Mutat. Res., 326: 147-153. 